\title{
Effect of training in the fasted state on metabolic responses during exercise with carbohydrate intake
}

Citation for published version (APA):

De Bock, K., Derave, W., Eijnde, B. O., Hesselink, M. K., Koninckx, E., Rose, A. J., Schrauwen, P., Bonen, A., Richter, E. A., \& Hespel, P. (2008). Effect of training in the fasted state on metabolic responses during exercise with carbohydrate intake. Journal of Applied Physiology, 104(4), 1045-55.

https://doi.org/10.1152/japplphysiol.01195.2007

Document status and date:

Published: 01/01/2008

DOI:

10.1152/japplphysiol.01195.2007

Document Version:

Publisher's PDF, also known as Version of record

Document license:

Taverne

Please check the document version of this publication:

- A submitted manuscript is the version of the article upon submission and before peer-review. There can be important differences between the submitted version and the official published version of record.

People interested in the research are advised to contact the author for the final version of the publication, or visit the DOI to the publisher's website.

- The final author version and the galley proof are versions of the publication after peer review.

- The final published version features the final layout of the paper including the volume, issue and page numbers.

Link to publication

\footnotetext{
General rights rights.

- You may freely distribute the URL identifying the publication in the public portal. please follow below link for the End User Agreement:

www.umlib.nl/taverne-license

Take down policy

If you believe that this document breaches copyright please contact us at:

repository@maastrichtuniversity.nl

providing details and we will investigate your claim.
}

Copyright and moral rights for the publications made accessible in the public portal are retained by the authors and/or other copyright owners and it is a condition of accessing publications that users recognise and abide by the legal requirements associated with these

- Users may download and print one copy of any publication from the public portal for the purpose of private study or research.

- You may not further distribute the material or use it for any profit-making activity or commercial gain

If the publication is distributed under the terms of Article $25 \mathrm{fa}$ of the Dutch Copyright Act, indicated by the "Taverne" license above, 


\title{
Effect of training in the fasted state on metabolic responses during exercise with carbohydrate intake
}

\author{
K. De Bock, ${ }^{1}$ W. Derave, ${ }^{1}$ B. O. Eijnde, ${ }^{1}$ M. K. Hesselink, ${ }^{2}$ E. Koninckx,${ }^{1}$ A. J. Rose, ${ }^{3}$ P. Schrauwen, ${ }^{4}$ \\ A. Bonen, ${ }^{5}$ E. A. Richter, ${ }^{3}$ and P. Hespel ${ }^{1}$ \\ ${ }^{1}$ Research Center for Exercise and Health, Department of Biomedical Kinesiology, K.U.Leuven, Belgium; ${ }^{3}$ Copenhagen \\ Muscle Research Centre, Institute of Exercise and Sports Sciences, University of Copenhagen, Copenhagen, Denmark; \\ ${ }^{2}$ Department of Movement Sciences and ${ }^{4}$ Department of Human Biology, NUTRIM, Maastricht University, The Netherlands; \\ ${ }^{5}$ Department of Human Health and Nutritional Sciences, University of Guelph, Canada
}

Submitted 9 November 2007; accepted in final form 31 January 2008

De Bock K, Derave W, Eijnde BO, Hesselink MK, Koninckx E, Rose AJ, Schrauwen P, Bonen A, Richter EA, Hespel P. Effect of training in the fasted state on metabolic responses during exercise with carbohydrate intake. J Appl Physiol 104: 1045-1055, 2008; doi:10.1152/japplphysiol.01195.2007.-Skeletal muscle gene response to exercise depends on nutritional status during and after exercise, but it is unknown whether muscle adaptations to endurance training are affected by nutritional status during training sessions. Therefore, this study investigated the effect of an endurance training program (6 wk, 3 day/wk, $1-2 \mathrm{~h}, 75 \%$ of peak $\dot{\mathrm{V}}_{2}$ ) in moderately active males. They trained in the fasted (F; $n=10)$ or carbohydratefed state $(\mathrm{CHO} ; n=10)$ while receiving a standardized diet [65 percent of total energy intake (En) from carbohydrates, 20\%En fat, $15 \%$ En protein]. Before and after the training period, substrate use during a 2-h exercise bout was determined. During these experimental sessions, all subjects were in a fed condition and received extra carbohydrates $\left(1 \mathrm{~g} \cdot \mathrm{kg}\right.$ body $\left.\mathrm{wt}^{-1} \cdot \mathrm{h}^{-1}\right)$. Peak $\dot{\mathrm{VO}}_{2}(+7 \%)$, succinate dehydrogenase activity, GLUT4, and hexokinase II content were similarly increased between $\mathrm{F}$ and $\mathrm{CHO}$. Fatty acid binding protein $(\mathrm{FABPm})$ content increased significantly in $\mathrm{F}(P=0.007)$. Intramyocellular triglyceride content (IMCL) remained unchanged in both groups. After training, pre-exercise glycogen content was higher in CHO $(545 \pm 19 \mathrm{mmol} / \mathrm{kg}$ dry wt; $P=0.02)$, but not in $\mathrm{F}(434 \pm 32$ $\mathrm{mmol} / \mathrm{kg}$ dry wt; $P=0.23$ ). For a given initial glycogen content, $\mathrm{F}$ blunted exercise-induced glycogen breakdown when compared with CHO $(P=0.04)$. Neither IMCL breakdown $(P=0.23)$ nor fat oxidation rates during exercise were altered by training. Thus shortterm training elicits similar adaptations in peak $\dot{\mathrm{V}}_{2}$ whether carried out in the fasted or carbohydrate-fed state. Although there was a decrease in exercise-induced glycogen breakdown and an increase in proteins involved in fat handling after fasting training, fat oxidation during exercise with carbohydrate intake was not changed.

human; substrate utilization; gene expression

IT IS WELL ESTABLISHED that carbohydrate intake during exercise delays the onset of fatigue and thereby improves endurance exercise performance $(10,20,32)$. This ergogenic effect is largely due to enhanced availability of blood glucose for energy provision in active muscles (12). However, evidence is also increasing to indicate that exercise in a carbohydratedepleted state can contribute to promoting training adaptations. The current understanding as to how endurance exercise training upregulates oxidative metabolism in muscle cells, is that rate-limiting metabolic proteins are upregulated by the cumu-

\footnotetext{
Address for reprint requests and other correspondence: P. Hespel, Research Center for Exercise and Health, F.A.B.E.R. - K.U.Leuven, Tervuursevest 101, B-3001 Leuven (Heverlee), Belgium (e-mail: peter.hespel@faber. kuleuven.be).
}

lative effect of transient increases in gene transcription in response to each exercise bout $(41,53)$. However, carbohydrate intake markedly blunts the exercise-induced increases in mRNA content of several genes $(11,16,50)$. Furthermore, Hansen and coworkers (24) recently reported a more pronounced increase in muscle glycogen content and citrate synthase activity as well as endurance performance following a 10 -wk training program if, due to training twice daily every second day, rather than once daily every day, one-half of the training sessions were performed in a glycogen-depleted state. This finding is compatible with earlier observations showing that low glycogen availability during exercise stimulates the transcription rate of a number of genes involved in training adaptation $(21,42)$. Taken together, the above findings indicate that decreasing carbohydrate availability during exercise by low initial muscle glycogen concentration triggers physiological adaptations that eventually are beneficial to endurance performance. Along this rationale, it is reasonable to assume that decreasing blood glucose availability by fasting prior and during exercise may be a valid alternative strategy to stimulate endurance training adaptations.

Acute exercise in the fasted state, compared with the carbohydrate-fed state, for a given exercise intensity and duration, stimulates the oxidation of fatty acids from both intramyocellular (16) and peripheral (17) fat depots. Total carbohydrate oxidation rate is correspondingly decreased, but this is probably mainly, if not entirely, due to reduced use of blood glucose because glycogen breakdown rate is well maintained (25) or even increased (15). The effects of long-term exercise in the fasted state have not been previously investigated. However, on the basis of the above acute effects it is probably reasonable to assume that consistent endurance exercise in the fasted state induces adaptations in muscle cells to facilitate energy provision through fat oxidation, while maintaining optimal capacity for glycogen breakdown during higher intensity episodes. In this regard, it is important to note that stimulation of fat use during exercise by training in conjunction with high-fat diet has been found to facilitate fat oxidation during exercise (28) yet impaired exercise-induced glycogen breakdown (8), which may be detrimental to performance.

Finally, because of the pivotal role of nutrition in training and performance, it is probably important to study training effects in a nutritional context that is relevant to athletes. As

\footnotetext{
The costs of publication of this article were defrayed in part by the payment of page charges. The article must therefore be hereby marked "advertisement" in accordance with 18 U.S.C. Section 1734 solely to indicate this fact.
} 
indicated above, training in a carbohydrate-deficient state due to glycogen depletion or fasting may be useful to promote adaptations to endurance training. However, at the end, such strategy must prove to be ergogenic in exercise with ample carbohydrate availability, which is the obvious and recommended dietary context for endurance exercise performance. Carbohydrate deficiency impairs endurance performance (32) and thus training strategies must have the potential to be ergogenic in exercise in a carbohydrate-loaded state.

Therefore, the aim of the present study was to compare the effects of endurance training in the fasted state vs. training in the carbohydrate-supplemented state on resting and exerciseinduced muscle gene and protein expression, and energy substrate selection during exercise with carbohydrate intake. Furthermore, to exclude possible confounding effects of diet, weight loss, or glycogen depletion $(52,54)$, subjects throughout the training period received a fully standardized carbohydrate-rich diet supplying an energy intake to maintain constant body weight. We hypothesized that exercise training in the fasted state more efficiently promotes adaptive responses of fat metabolic genes and proteins compared with a similar training load in combination with high rate of carbohydrate intake. As a result of such adaptations, training in the fasted state should also stimulate the relative contribution of fat oxidation to energy production during submaximal exercise with carbohydrate intake.

\section{METHODS}

\section{Subjects}

Twenty healthy, physically active men (age: $21.2 \pm 0.4 \mathrm{yr}$; body wt: $74.8 \pm 2.0 \mathrm{~kg}$ ) volunteered to participate in the study, which was approved by the local Ethics Committee (K.U.Leuven). Subjects were instructed not to participate in any strenuous physical activity, except for the exercise sessions prescribed by the study protocol. Subjects gave their written, informed consent after they were informed in detail of all experimental procedures and risks possibly associated with the experiments.

\section{Preliminary Testing}

Two weeks before the first experimental trial, subjects performed an incremental exercise test (initial load $100 \mathrm{~W}+40 \mathrm{~W} / 8 \mathrm{~min}$ ) on a bicycle ergometer (Avantronic Cyclus II, Leipzig, Germany) 90 min after the intake of a light breakfast to determine the rate of peak oxygen uptake $\left(\mathrm{V}_{2}\right.$ peak $)$, time to exhaustion, and the exercise intensity corresponding with the lactate threshold (LT). Oxygen uptake rate was measured using a breath-by-breath ergospirometry system (Jaeger Oxycon Alpha). LT was determined as the exercise intensity at which lactate concentrations increased by $>1 \mathrm{mmol} / \mathrm{l}$ above baseline during steady-state conditions (13). Furthermore, subjects participated in two familiarization sessions during which they performed a 2-h constant load exercise bout on the bicycle ergometer following a breakfast. Rate of carbohydrate intake during exercise was $1 \mathrm{~g} \cdot \mathrm{kg}$ body $\mathrm{wt}^{-1} \cdot \mathrm{h}^{-1}$. During the first familiarization session, subjects were allowed to continuously adjust the workload (watt) to tune the required workload to reach exhaustion by $2 \mathrm{~h}$ of exercise. This workload was further adjusted during the second familiarization trial and was eventually used during the experimental sessions $(171 \pm 4 \mathrm{~W})$.

\section{Experimental Protocol}

Subjects participated in two experimental sessions (Pretraining and Posttraining), with a 6-wk training period in between. On the morning of the pretraining, subjects reported to the laboratory between 6:00 and 10:00 AM after an $\sim 11$ h overnight fast. They received a standardized carbohydrate-rich breakfast $[722 \mathrm{kcal}: 85$ percent of total energy intake (En) carbohydrates, $4 \%$ En from fat, $11 \%$ En from protein]. After a 2-h rest period, a percutaneous needle biopsy sample was taken from the right vastus lateralis muscle under local anesthetic through a $5-\mathrm{mm}$ incision in the skin (2-3 $\mathrm{ml}$ lidocaine). Furthermore, $25 \mathrm{ml}$ blood was sampled from an antecubital vein. Thereafter subjects cycled for $2 \mathrm{~h}$ at a constant workload, which was determined during the familiarization sessions $(171 \pm 4 \mathrm{~W})$. After $10 \mathrm{~min}, 60$ min, and at the end of the exercise bout, oxygen uptake $\left(\dot{\mathrm{V}}_{2}\right)$ and carbon dioxide output $\left(\dot{\mathrm{V}}_{\mathrm{CO}_{2}}\right)$ were measured over a 5-min interval using a breath-by-breath ergospirometry system (Jaeger, Oxycon Alpha). Capillary blood was sampled from a hyperemic earlobe before and immediately after exercise for determination of blood glucose concentration. During the exercise bout subjects received $1 \mathrm{~g}$ maltodextrine $\cdot \mathrm{kg}$ body $\mathrm{wt}^{-1} \cdot \mathrm{h}^{-1}$ in a $15 \%$ solution. At the end of the exercise bout, another muscle biopsy and a venous blood sample were taken. The muscle biopsy was taken through the same incision as the pre-exercise biopsy, but with the needle pointing another direction. During the following 4-h recovery period, the subjects rested in the laboratory. They received $1.5 \mathrm{~g}$ maltodextrin $/ \mathrm{kg}$ body wt $(15 \%$ flavored solution) during the initial and the last hour of recovery. Furthermore, between 2 and $3 \mathrm{~h}$ of recovery, they received a solid meal containing $1.5 \mathrm{~g}$ carbohydrates/kg body wt. The subjects were allowed to drink additional water throughout, but the volume consumed during the first trial was recorded and reproduced during the second trial. At the end of the recovery period another muscle sample was taken through a new incision in the contralateral leg.

\section{Training Protocol}

After the last familiarization session, subjects were pair-matched to obtain two experimental groups with similar distributions for performance level $\left(\mathrm{W}_{\text {mean }}\right.$ during the 2-h time trial) and dietary energy intake $(\mathrm{kcal} / 24 \mathrm{~h})$ and were randomly assigned to one of the two groups. Thereafter they were enrolled in a 6-wk supervised training program combined with a dietary control regimen (see Dietary Control). One-half of the subjects trained in the fasted state (F; $n=10)$, whereas the other group $(\mathrm{CHO} ; n=10)$ received a carbohydrate-rich breakfast $\sim 90$ min before each training session. Furthermore, $\mathrm{CHO}$ ingested maltodextrin ( $15 \%$ solution) during exercise at a rate of 1 $\mathrm{g} \cdot \mathrm{kg}$ body $\mathrm{wt}^{-1} \cdot \mathrm{h}^{-1}$, while $\mathrm{F}$ received a similar volume of water. Subjects trained three times weekly (Monday, Wednesday, and Friday) between 7 and 12 AM, and training duration was progressively increased from 60 to $120 \mathrm{~min}$. Subjects from F and CHO consistently trained as matched pairs. However, F subjects were instructed to adjust the workload to obtain a heart rate that was similar to the first experimental session, while $\mathrm{CHO}$ subjects had to adjust the workload to their pair-matched $F$ subject. Thus training duration and intensity were similar between groups at all times.

At the end of the 6-wk intervention period, the subjects repeated the incremental exercise test to assess post-training $\dot{V}_{2}$ peak and LT. Forty-eight hours after the last training session, subjects participated in the posttraining, which was identical to the pretraining.

\section{Dietary Control}

Before the start of the study, a 4-day dietary record was performed. Energy intake was calculated using a nutritional software package (Becel 5.00, Unilever Bestfoods, Rotterdam, The Netherlands). Carbohydrate-rich standard diets $(65 \%$ En carbohydrates, $20 \%$ En fat, $15 \%$ En proteins) were composed for each subject to correspond to the daily energy intake recorded before the study. From Monday to Friday, a supervised lunch was served, whereas all other meals, snacks, and drinks were provided as individual take home food packages, accompanied with a personal menu indicating the approximate timing of food intake (breakfast, lunch, 4 PM snack, supper, and evening snack). On training days, energy intake was increased to 
compensate for the calculated energy expenditure in the exercise sessions to maintain a constant body weight (see RESULTS). Moreover, to obtain identical daily energy intakes $(2,865 \pm 151 \mathrm{kcal} /$ day $)$ between the groups, in the afternoon F received the "breakfast" plus the $1 \mathrm{~g} / \mathrm{kg}$ body wt maltodextrin solution corresponding with the carbohydrate intake before and during exercise in CHO. For the weekends, subjects received dietary instructions and completed a food diary, but meals were not supervised. Analysis of the food records showed that energy consumption during the weekends was similar between groups and not different from weekdays (data not shown). To avoid fluctuations of IMCL content due to variations in dietary fat intake (3), care was taken that the diet during the 3 days before the experimental session was identical between Pretraining and Posttraining.

\section{Analysis of Muscle Samples}

Muscle biopsy handling. After removal of any visible non-muscle material, part of the muscle sample was immediately frozen in liquid nitrogen and the remaining part was mounted in embedding medium (Tissue-Tek, Sakura FineTek, Zoeterwoude, The Netherlands) cooled in isopentane. All samples were stored at $-80^{\circ} \mathrm{C}$ for later analysis. Muscle glycogen content was measured as glucose residues after acid hydrolysis in freeze-dried muscle tissue using a standard enzymatic fluorometric assay (36).

Histological analyses. Serial sections $(4 \mu \mathrm{m})$ from biopsy samples collected before, immediately after, and $4 \mathrm{~h}$ after exercise (pre- and posttraining) were laid together on uncoated glass slides. Fiber typedependent staining for ICML was performed using the Oil-Red-O (ORO) technique as previously described (16). Muscle fiber typespecific oxidative capacity was estimated by assessing succinate dehydrogenase (SDH) activity in the muscle cryosections using histochemical analyses (31). For the SDH assay, pilot experiments revealed the optimal time $(1 \mathrm{~h})$ to terminate the enzyme reaction while it was still linear (data not shown).

ORO staining. Briefly, cryosections were fixed in $4 \%$ paraformaldehyde for $1 \mathrm{~h}$ and treated with $10 \mathrm{mM} \mathrm{NH}_{4} \mathrm{Cl}$. After a 30-min prehybridization, they were incubated overnight at $4^{\circ} \mathrm{C}$ with two primary monoclonal antibodies against human myosin heavy chain I (A4.840 supernatant, Developmental Studies Hybridoma Bank, IA) and IIa (N2.261 supernatant, Developmental Studies Hybridoma Bank). The morning after, the appropriate conjugated antibodies (type I: Alexa Fluor350 anti-mouse IgG1 Molecular Probes, Leiden, The Netherlands; type IIa: FITC anti-mouse IgM Southern Biotechnology Associates, Birmingham, AL) were added ( $1 \mathrm{~h})$ and ORO was performed. Muscle sections were incubated in formalin for $10 \mathrm{~min}$ and stained for $15 \mathrm{~min}$ with the ORO working solution. After the immersion in ORO, sections were washed with deionized water $\left(\mathrm{ddH}_{2} \mathrm{O}\right.$; $25 \times 3 \mathrm{~s}$ ) and then coverslips were mounted. Due to the exclusion of Triton X-100 out of the fixation medium and some small adaptations in the washing procedure, we were able to cut down the intra-assay coefficient of variation to $7 \%$.

SDH activity. Cryosections were incubated for $1 \mathrm{~h}$ at $37^{\circ} \mathrm{C}$ in a 0.2 $\mathrm{M}$ sodium phosphate buffer containing $0.1 \mathrm{M}$ succinic acid (SigmaAldrich) and $1.2 \mathrm{mM}$ nitro-blue tetrazolium (AppliChem; NBT). Next, sections were briefly rinsed with $\mathrm{ddH}_{2} \mathrm{O}$ followed by three successive exchanges in 30,60 , and $90 \%$ acetone in $\mathrm{ddH}_{2} \mathrm{O}$, respectively. Thereafter, sections were incubated for $1 \mathrm{~h}$ with the myosin heavy chain antibodies followed by the appropriate secondary antibodies ( $1 \mathrm{~h})$, to permit fiber type-specific SDH analysis.

Image capturing, processing, and analysis. Slides were examined using a Nikon E1000 fluorescence microscope (Nikon, Boerhavedorp, Germany) equipped with a digital camera. Epifluorescence signal was recorded using a Texas red excitation filter for ORO, and FITC and DAPI filter for type I and IIa muscle fibers, respectively. Fibers negatively stained for type I and IIa fibers were qualified as type IIx fibers. Because of a too small number $(<10)$ of type IIx fibers in a high proportion of the muscle samples, no separate analyses for type
IIx fibers were performed. Images for SDH-stained sections were examined in bright field and special care was taken to capture images with identical camera (exposure time: $2 \mathrm{~ms}$ ) and microscopy (light intensity: $11.3 \mathrm{~V}$; ND filter: $\left.72^{\circ}\right)$ settings. Captured images $(\times 20$ magnification) were processed and analyzed using Lucia $\mathrm{G}$ software (LIM, Prague, Czech Republic). The bright-field images were converted post hoc to grayscale values and the mean optical density of each fiber was semi-quantified. Mean optical density of a selected region outside the muscle section, which was equal to the optical density of the sections after incubation in a reaction medium without the substrate, was used for background correction. For the ORO signal, an intensity threshold representing minimal intensity values corresponding to lipid droplets was set manually and uniformly used for all subjects. Fiber type-specific IMCL content was expressed as arbitrary units. At least 150 muscle cells per section were analyzed.

RNA extraction and reverse transcription. Total RNA from frozen muscle samples was extracted using an ABI Prism 6100 Nucleic Acid Prep station (Applied Biosystems). Extracts were stored at $-80^{\circ} \mathrm{C}$ until used for real-time PCR analysis at a later date. Total RNA was reverse transcribed using the high-capacity cDNA archive kit (Applied Biosystems) according to the manufacturer's instructions.

Real-time qPCR analysis. Primers and probes for real-time PCR were designed by Applied Biosystems and supplied as an assay-ondemand Gene Expression Assay mix containing a $20 \times$ mix of unlabeled PCR forward and reverse primers as well as Taqman MGB probe. Assay IDs were Hs00168966 (GLUT4), Hs00243297 (UCP3), Hs00176875 (PDK4), Hs00606086 (HKII), Hs00169627 (CD36), Hs00426191 ( $\beta$-HAD), Hs00189258 (CPT1), and Hs99999903 ( $\beta$ actin). Real-time qPCR was carried out in a $20 \mu \mathrm{l}$ reaction mixture with $5 \mu \mathrm{l}$ cDNA, $4 \mu \mathrm{l}$ Rnase-free water, $1 \mu \mathrm{l}$ of $20 \times$ assay-ondemand gene expression assay mix, and $10 \mu \mathrm{l}$ of the $2 \times$ Taqman universal PCR master mix, containing ROX as a passive reference dye (Applied Biosystems). Amplification and detection were performed using the ABI PRISM 7300 sequence detection system (Applied Biosystems). Thermal cycling conditions included initial $2 \mathrm{~min}$ at $50^{\circ} \mathrm{C}$ and $10 \mathrm{~min}$ at $95^{\circ} \mathrm{C}$ followed by 45 two-step cycles including denaturation of $15 \mathrm{~s}$ at $95^{\circ} \mathrm{C}$ and annealing/extension of $60 \mathrm{~s}$ at $60^{\circ} \mathrm{C}$. Each gene was analyzed with the incorporation of a negative control. All reactions were performed in triplicate. To compensate for variations in input RNA amounts and efficiency of reverse transcription, $\beta$-actin mRNA was quantified, and results were normalized to these values. Gene expression data are represented with resting samples before training assigned the arbitrary value of 1.0 and all other samples expressed relative to this value.

Muscle lysate production. Muscle specimens were freeze-dried and dissected free of visible blood, connective, and fat tissues. Samples were then homogenized in ice-cold buffer $(20 \mathrm{mM}$ Tris base, $50 \mathrm{mM}$ $\mathrm{NaCl}, 2 \mathrm{mM}$ DTT, $50 \mathrm{mM} \mathrm{NaF}, 1 \%$ Triton X-100, $250 \mathrm{mM}$ sucrose, $5 \mathrm{mM}$ Na-pyrophosphate, $4 \mu \mathrm{g} / \mathrm{ml}$ leupeptin, $6 \mathrm{mM}$ benzamedine, 500 $\mu \mathrm{M}$ PMSF, $50 \mu \mathrm{g} / \mathrm{ml}$ soybean trypsin inhibitor, $\mathrm{pH}$ 7.4) for $20 \mathrm{~s}$ using a homogenizer (Polytron 2000, Kinematica, Littau, Switzerland). Homogenates were rotated end over end for $1 \mathrm{~h}$ at $4^{\circ} \mathrm{C}$. Lysates were generated by centrifugation $(17,500 \mathrm{~g})$ for $1 \mathrm{~h}$ at $4^{\circ} \mathrm{C}$. Lysates were quick frozen in liquid nitrogen and stored at $-80^{\circ} \mathrm{C}$. Protein content in lysates was measured by the bicinchoninic acid method (Pierce Chemical).

Western blotting. HKII (hexokinase II), GLUT4, UCP3 (uncoupling protein 3), CD36, and FABPm (membrane-bound fatty acid binding protein) protein expression were determined as described previously $(5,22,39,49)$. Protein expression data are represented with resting samples before training assigned the arbitrary value of 1.0 and all other samples expressed relative to this value.

\section{Analysis of Blood Samples}

Venous blood samples were collected into vacuum tubes containing either EDTA or lithium heparin or Silica Clot Activator (BD 
Vacutainer). Tubes were centrifuged $\left(1,500 \mathrm{rpm}\right.$ for $15 \mathrm{~min}$ at $\left.4^{\circ} \mathrm{C}\right)$ and the supernatant was stored at $-80^{\circ} \mathrm{C}$ until later analysis. Capillary blood samples were collected $(50 \mu \mathrm{l})$ into heparinzed glass capillaries and were immediately analyzed for blood glucose concentration using an Analox GM7 analyzer (Analox Instruments, London, UK). Plasma insulin (Human Insulin, Biotech-IgG) was assayed using a commercially available radioimmunoassay kit. Plasma catecholamines were determined by means of a high performance liquid chromatography method using electrochemical detection.

\section{Data Calculations and Statistical Analyses}

Carbohydrate and fat oxidation rates were calculated from the measured $\dot{\mathrm{V}}_{2}$ and $\dot{\mathrm{V}}_{2}$ values according to the following equations (40): fat oxidation rate $(\mathrm{g} / \mathrm{min})=1.6946 \dot{\mathrm{V}}_{2}-1.7012 \dot{\mathrm{VCO}}_{2}$ and carbohydrate oxidation rate $(\mathrm{g} / \mathrm{min})=4.5850 \dot{\mathrm{V}} \mathrm{CO}_{2}-3.2255 \dot{\mathrm{V}}_{2}$.

Treatment effects were evaluated using a repeated-measures ANOVA. Two-way ANOVA was performed to examine the main effects of treatment and/or time. In case the ANOVA yielded a significant effect, a planned contrast analysis was used for post hoc comparisons. In addition, contrast analysis was also used to evaluate specific preplanned comparisons. In both Pretraining and Posttraining, the relation between initial glycogen content and net glycogen breakdown was assessed by the regression slope and its standard error, obtained from a regression analysis. Difference between slopes was tested by the probability of its $t$ value. Furthermore, to correct for the conceivable effect of differential initial glycogen content $(26,30)$, exercise-induced changes in muscle glycogen content were evaluated by an ANCOVA with initial glycogen content as a covariant. The strength of association between parameters was analyzed by Pearson product moment correlation analysis. A probability level $(P) \leq 0.05$ was considered statistically significant. All data are expressed as means \pm SE.

\section{RESULTS}

\section{Exercise Capacity and Body Weight}

Subjects performed an incremental exercise test before and at the end of the training program. Independent of the experimental condition, the 6-wk training period increased time to exhaustion from $49 \pm 2$ to $54 \pm 2 \min (P=0.0001) . \dot{V}_{o_{2 p e a k}}$ increased from $52.9 \pm 1.5$ to $56.7 \pm 1.6 \mathrm{ml} \cdot \mathrm{min}^{-1} \cdot \mathrm{kg}^{-1}$ in $\mathrm{F}$ $(P=0.004)$ and from $54.3 \pm 1.6$ to $56.8 \pm 1.2 \mathrm{ml} \cdot \mathrm{min} \cdot \mathrm{kg}^{-1}$ in $\mathrm{CHO}(P=0.04)$ and was not different between groups. LT occurred at a workload of $176 \pm 6 \mathrm{~W}$ during Pretraining and increased by $\sim 8 \%$ in either group to $190 \pm 5 \mathrm{~W}$ at Posttraining. Thus, during Pretraining, subjects performed the 2-h exercise bout at $73 \pm 1 \% \dot{\mathrm{V}}_{2 \text { peak }}$ and workload $(171 \pm 4 \mathrm{~W})$ corresponded to $98 \pm 1 \% \mathrm{LT}$. After training, they cycled at same absolute workload, which corresponded to $64 \pm 2 \%(P=$ 0.0004 vs. Pretraining) of Posttraining $\dot{V}_{\mathrm{o}_{2} \text { peak }}$ and $90 \pm 2 \%$ $(P=0.001)$ of LT. Relative exercise intensities were identical between groups during both Pretraining and Posttraining.

The dietary control regimen associated with the training program was successful in maintaining constant body weight. Body weight was $74.3 \pm 2.8$ in $\mathrm{F}$ vs. $75.3 \pm 3 \mathrm{~kg}$ in $\mathrm{CHO}$ during Pretraining and was similar during Posttraining $(\mathrm{F}$ : $74.2 \pm 3.0 \mathrm{~kg}$; CHO: $75.5 \pm 2.9 \mathrm{~kg}$ ).

\section{Training Effects in Muscle at Rest}

Protein contents and SDH activity. GLUT4 $(P=0.049)$ and HKII $(P<0.001)$, but not UCP3, protein content were increased after training (Fig. 1, Table 1). The training-induced increases in GLUT4 and HKII were independent of the exper-
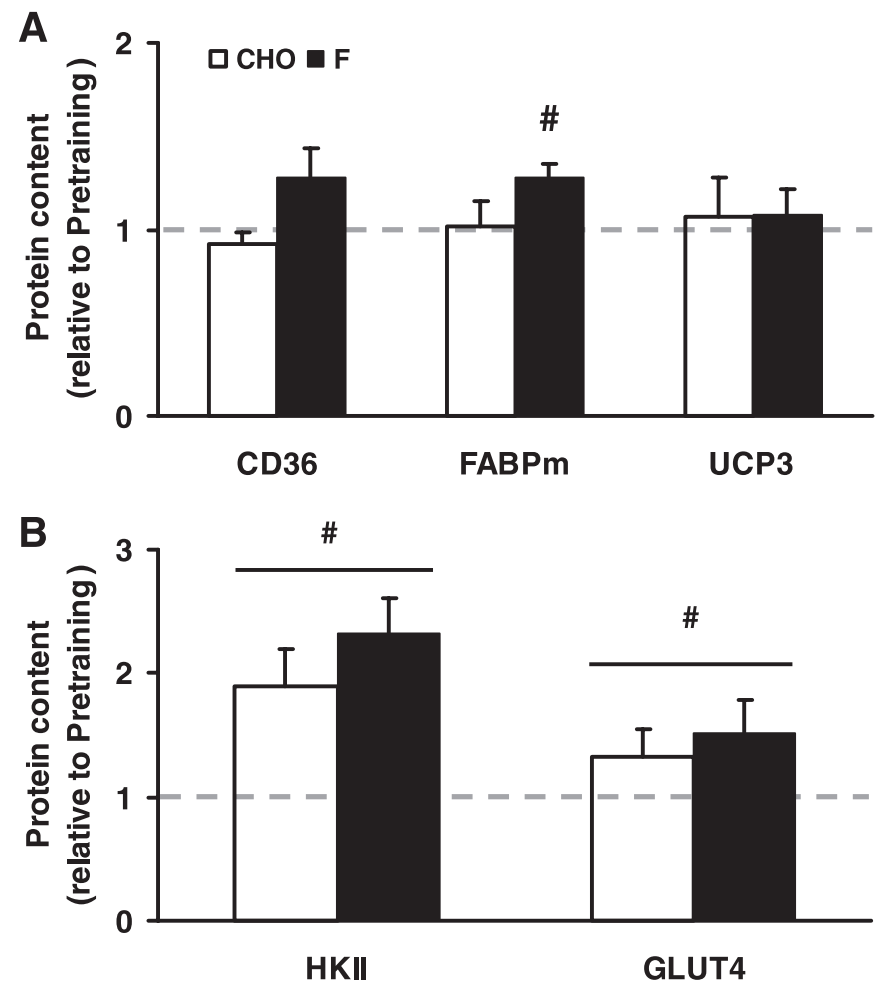

C

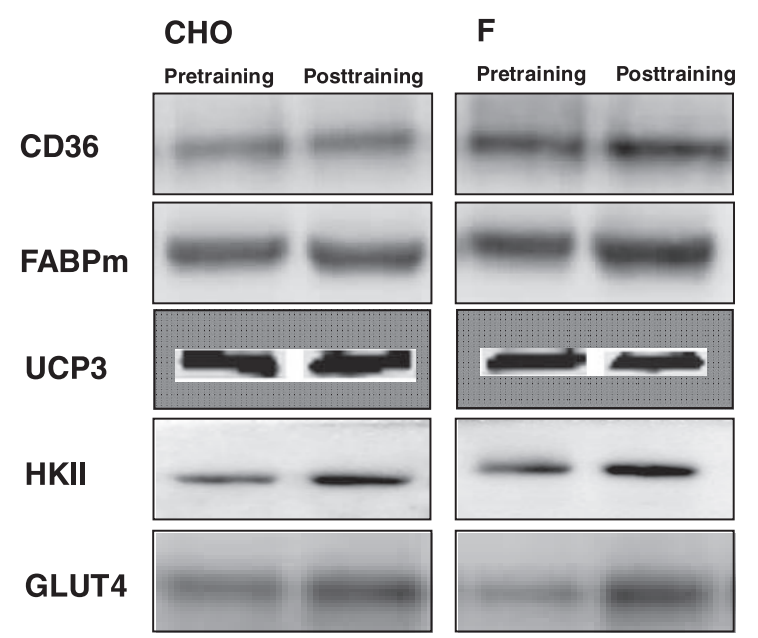

Fig. 1. Effect of training in the fasted (F) vs. carbohydrate-fed state $(\mathrm{CHO})$ on CD36, FABPm, UCP3, HKII, and GLUT4 protein content in resting muscles. Protein content of CD36, FABPm, and UCP3 $(A)$ and HKII and GLUT4 $(B)$ was measured by Western blotting on resting muscle samples obtained before (Pretraining) and after (Posttraining) a 6-wk training period. Values are given as protein content relative to the pretraining value and are expressed as means \pm SE (F: $n=10$; CHO: $n=9$ ). $\# P<.05$ vs. Pretraining. Representative blots are shown in $C$.

imental conditions. Training in the fasted state increased protein content of FABPm $(P=0.007)$ but not CD36 $(P=0.11)$. However, the lack of statistical significance in CD36 protein content could be attributed to one subject that showed a decrease in CD36 and FABPm content after F. Omitting this outlier turned the increase in CD36 protein content into significance $(P=0.05)$. Pretraining SDH activity was consistently higher in type I than in type IIa fibers $(P<0.001)$, but similar between groups. In both experimental conditions, the 
Table 1. Effect of training in the fasted versus carbohydratefed state on SDH activity

\begin{tabular}{lcccccc}
\hline \hline \multirow{2}{*}{ State } & \multicolumn{2}{c}{ Type I Fibers } & & \multicolumn{2}{c}{ Type IIa Fibers } & \\
\cline { 2 - 3 } & Pretraining & Posttraining & & Pretraining & Posttraining & $P$ Value \\
\hline $\mathrm{F}$ & $8.4 \pm 1.2$ & $11.5 \pm 1.4^{*}$ & & $6.0 \pm 1.0$ & $8.8 \pm 1.2^{*}$ & $<.0001$ \\
$\mathrm{CHO}$ & $9.2 \pm 0.8$ & $11.6 \pm 0.5^{*}$ & & $7.4 \pm 0.9$ & $8.8 \pm 0.7$ & \\
\hline
\end{tabular}

Data are expressed as means \pm SE. SDH (in arbitrary units) activity for type I and type IIa fibers before (Pretraining) and after (Posttraining) a 6-wk training period as determined by histochemical staining. F, fasted; $\mathrm{CHO}$, carbohydrate fed. ${ }^{*} P<0.05$ compared with Pretraining. No interaction between training and group was detected.

training equally increased SDH activity in type I fibers by $\sim 30 \%$ ( $P<0.001)$. In type IIa fibers SDH activity was increased in $\mathrm{F}(+47 \%, P=0.004)$ and to a lesser extent in CHO $(+20 \%, P=0.11)$.

$m R N A$ content. During Pretraining, muscle mRNA content was similar between groups for all genes measured (Figs. 2 and 3). However, training reduced CD36, UCP3, CPT1, and PDK4 mRNA content by $\sim 40-50 \%$ in F, but not in CHO. GLUT4 mRNA content was slightly reduced only in $\mathrm{CHO}(P<$ 0.0001 ) but not in $\mathrm{F}$, whereas $\beta$-HAD mRNA content was lower after training in both groups.

Energy substrates. During Pretraining, pre-exercise muscle glycogen content was similar between groups $(\sim 400 \mathrm{mmol} / \mathrm{kg}$ dry wt; Figs. 4 and 5).Training increased initial muscle glycogen content in $\mathrm{CHO}(545 \pm 19 \mathrm{mmol} / \mathrm{kg}$ dry wt; $P=0.02)$, but not in F (434 $\pm 32 \mathrm{mmol} / \mathrm{kg}$ dry wt; $P=0.23)$. In the pretraining, initial IMCL content (Fig. 5) was similar in both groups and was approximately twofold higher in type I fibers than in type IIa fibers $(11 \pm 1$ vs. $20 \pm 1$ arbitrary units, $P<$ 0.001). Six weeks of training did not alter IMCL content in either group or fiber type.

\section{Training Effects on Acute Exercise Responses}

$m R N A$ content. During Pretraining, exercise reduced mRNA content of the fat metabolic genes CD36, $\beta$-HAD, CPT1, and UCP3 by $\sim 30-50 \%$ immediately after exercise, independent of the experimental condition. Values returned to baseline within the 4-h recovery period, except UCP3 mRNA content, which was suppressed until 4-h postexercise $(P=0.03)$. During Posttraining in $\mathrm{CHO}$, exercise decreased CD36 $(P=$ $0.02)$ and CPT1 $(P=0.01)$, but not $\beta$-HAD or UCP3 mRNA content. All mRNA levels had returned to baseline levels after $4 \mathrm{~h}$ of recovery. Conversely in F, mRNA expression of CD36, $\beta-H A D, C P T 1$, and UCP3 was increased by exercise or recovery. In both the Pretraining and the Posttraining and independent of the experimental condition, the mRNA levels of PDK4 were reduced after exercise, whereas HKII was increased after $4 \mathrm{~h}$ of recovery $(P=0.008)$.

Muscle energy substrates. In the pretraining, exercise decreased glycogen content to the same degree $(\sim 60 \%)$ in either group (Fig. 4). The 6-wk training period tended to blunt exercise-induced net glycogen breakdown in F vs. $\mathrm{CHO}(P=$ $0.10)$. Thus, in $\mathrm{F}$, net glycogen breakdown over the 2-h exercise bout was $212 \pm 31 \mathrm{mmol} / \mathrm{kg}$ dry wt in the Pretraining vs. $139 \pm 20 \mathrm{mmol} / \mathrm{kg}$ dry wt in the posttraining. Corresponding values in CHO were $267 \pm 43$ and $304 \pm 28 \mathrm{mmol} / \mathrm{kg}$ dry wt. ANCOVA indicated that the differential training effect
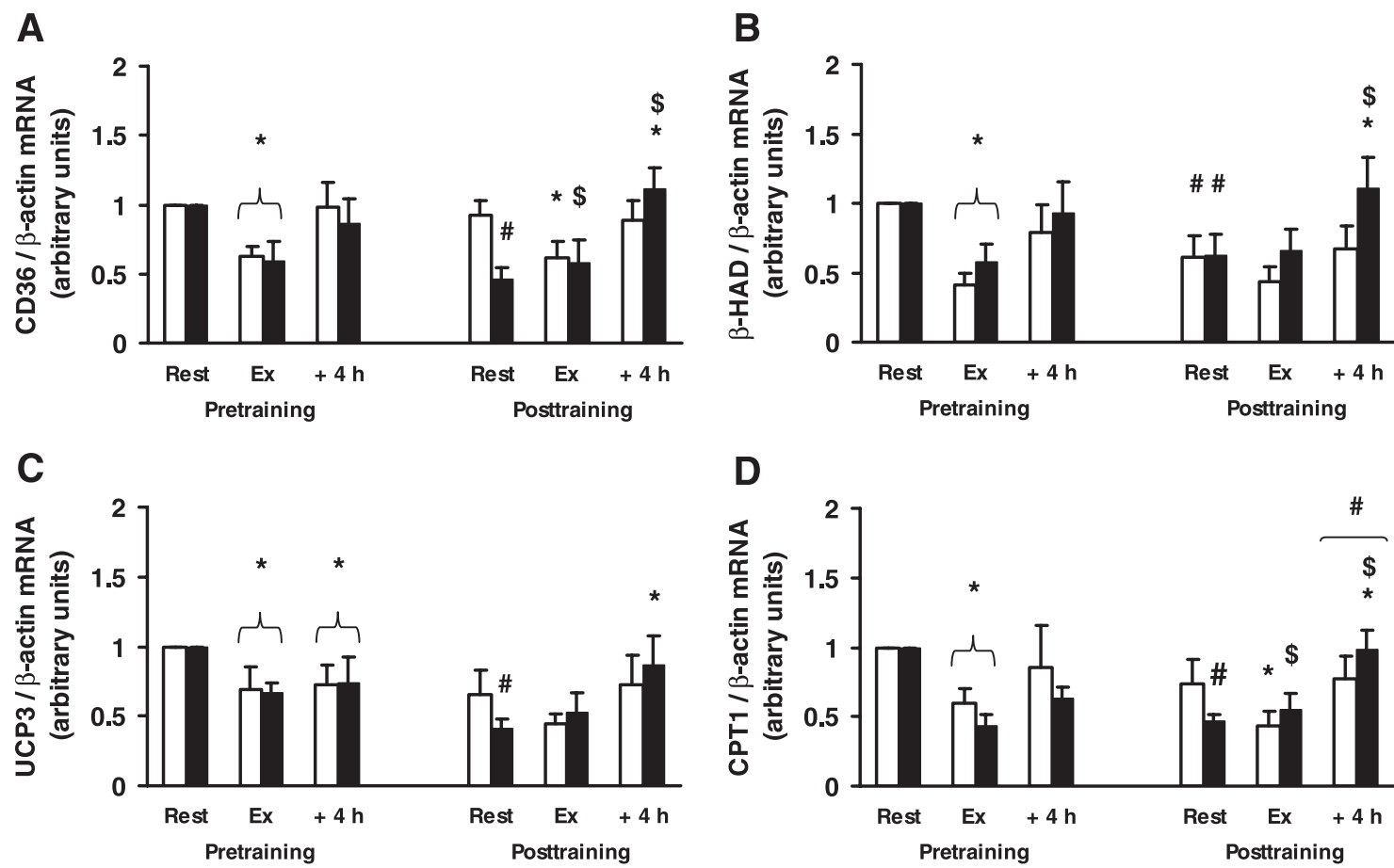

Fig. 2. Effect of a single exercise bout with carbohydrate intake before and after 6 wk of training in $\mathrm{F}$ vs. CHO on muscle mRNA content of CD36, $\beta$-HAD, UCP3, and CPT1. Skeletal muscle mRNA content of CD36 (A), $\beta$-HAD $(B)$, UCP3 $(C)$, and CPT1 $(D)$ was measured by RT-PCR before (Rest), immediately after $($ Ex $)$, and $4 \mathrm{~h}$ after $(+4 \mathrm{~h})$ a 2-h constant-load exercise bout. Values are expressed relative to baseline values (Rest-Pretraining), which were set equal to one. Data shown are normalized for $\beta$-actin and expressed as means \pm SE (F: $n=10$; CHO: $n=10)$. CHO: open bars; F: filled bars. $* P<0.05$ indicates a difference compared with rest. $\# P<0.05$ indicates a difference compared with the corresponding value during pretraining. $\$ P<0.05$ indicates that the exercise-induced change in muscle mRNA content is different from $\mathrm{CHO}$. 

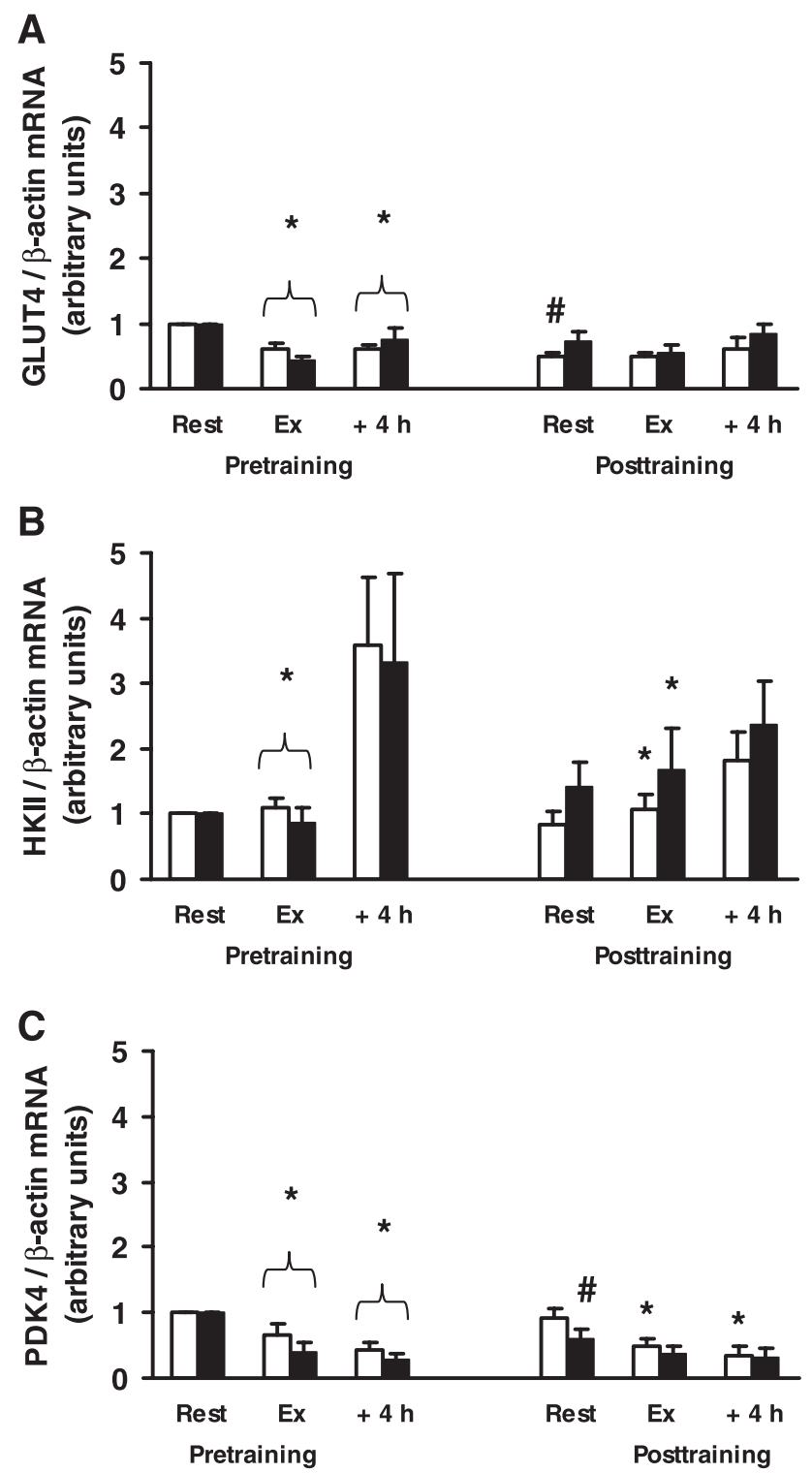

Fig. 3. Effect of a single exercise bout with carbohydrate intake before and after 6 wk of training in F vs. CHO on mRNA content of GLUT4, HKII, and PDK4. Skeletal muscle mRNA content of GLUT4 (A), HKII $(B)$, and PDK4 (C) was measured by RT-PCR before (Rest), immediately after (Ex), and $4 \mathrm{~h}$ after $(+4 \mathrm{~h})$ a $2-\mathrm{h}$ constant-load exercise bout. Values are expressed relative to baseline values (Rest-Pretraining), which were set equal to one. Data shown are normalized for $\beta$-actin and expressed as means \pm SE (F: $n=10$; CHO: $n=10$ ). $\mathrm{CHO}$, open bars; F: filled bars. ${ }^{*} P<0.05$ indicates a difference compared with Rest. \#P $<0.05$ indicates a difference compared with the corresponding value during pretraining.

between $\mathrm{F}$ and $\mathrm{CHO}$ was not explained by different initial glycogen contents $(P<0.01)$. Therefore, we evaluated the relationship between initial glycogen content and net glycogen breakdown during exercise. During Pretraining net glycogen breakdown over the 2-h exercise bout closely correlated with initial glycogen concentration in both CHO $(r=0.87, \mathrm{y}=$ $0.766 \mathrm{x}-59 ; P<0.001)$ and $\mathrm{F}(r=0.80, \mathrm{y}=0.733 \mathrm{x}-65$; $P=0.006$ ), and the slope of the regression was identical between the groups. However, during Posttraining the slope of the regression between initial glycogen content and glycogen breakdown was significantly steeper in $\mathrm{CHO}(\mathrm{y}=1.162 \mathrm{x}-$
$329 ; r=0.81, P=0.05)$ than in $\mathrm{F}(\mathrm{y}=0.403 \mathrm{x}-36 ; r=0.65$, $P=0.04)$. During Pretraining as well as Posttraining, the 2-h exercise bout decreased IMCL content by $\sim 25 \%$ in both $\mathrm{F}$ and CHO $(P<0.001$; Fig. $5 B)$. Net IMCL breakdown did not occur in type IIa fibers during exercise at any time.

Respiratory measurements. Substrate oxidation rates during the constant-load tests were calculated from the $\mathrm{V}_{2}$ and $\dot{\mathrm{V}}_{\mathrm{CO}_{2}}$ measurements (Table 2). Compared with Pretraining and independent of the experimental condition, $\dot{\mathrm{V}}_{2}(P=0.02)$ and $\dot{V} \mathrm{CO}_{2}$ during Posttraining decreased by $\sim 7 \%(P<0.001)$. Hence respiratory exchange ratios were similar between the Pretraining and the Posttraining. Calculated rates of carbohydrate and fat oxidation were neither significantly affected by the training per se nor by the experimental conditions.

\section{Circulating Hormones and Glycemia}

In the Pretraining, but not in the Posttraining $(P=0.18)$, pre-exercise plasma insulin concentration was slightly higher in $\mathrm{F}$ than in $\mathrm{CHO}(P=0.02$; Table 3$)$. Exercise decreased plasma insulin $(P=0.0001)$, but exercise-induced changes in plasma insulin were similar between groups, either before or after the 6 -wk training period $(P=0.81)$. Pre-exercise plasma epinephrine concentrations were similar between groups at any time and values increased during exercise $(P<0.001)$, except in $\mathrm{CHO}$ during Posttraining. During Pretraining, resting plasma norepinephrine tended to be lower in $\mathrm{F}$ than in $\mathrm{CHO}(P=$ 0.07). Exercise increased norepinephrine concentrations to the
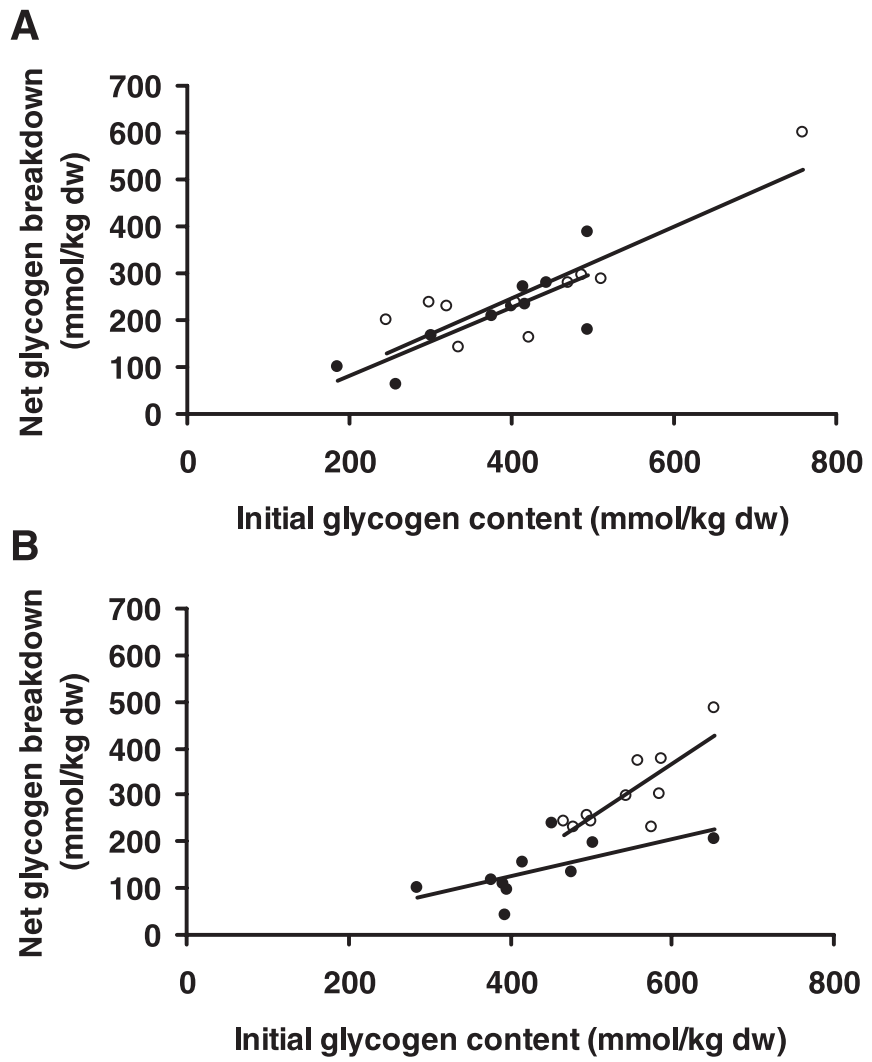

Fig. 4. Effect of training in $\mathrm{F}$ vs. $\mathrm{CHO}$ on the relationship between initial glycogen content and net glycogen breakdown during exercise with carbohydrate intake. The relationship between initial glycogen content and net glycogen breakdown during a 2-h constant load cycling bout with carbohydrate intake during Pretraining $(A)$ and Posttraining $(B)$. $\odot$, CHO $(n=10)$; $\bullet$ F $(n=10)$. 

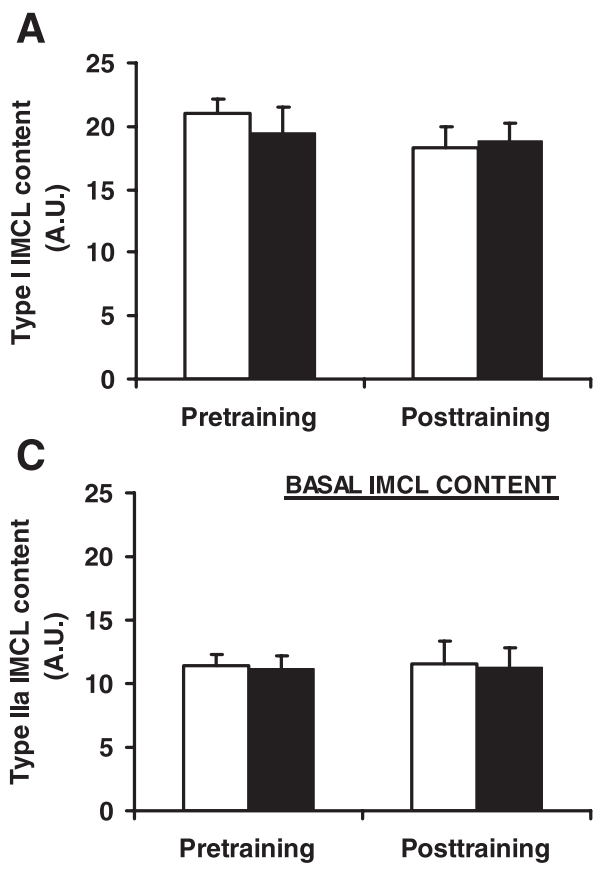
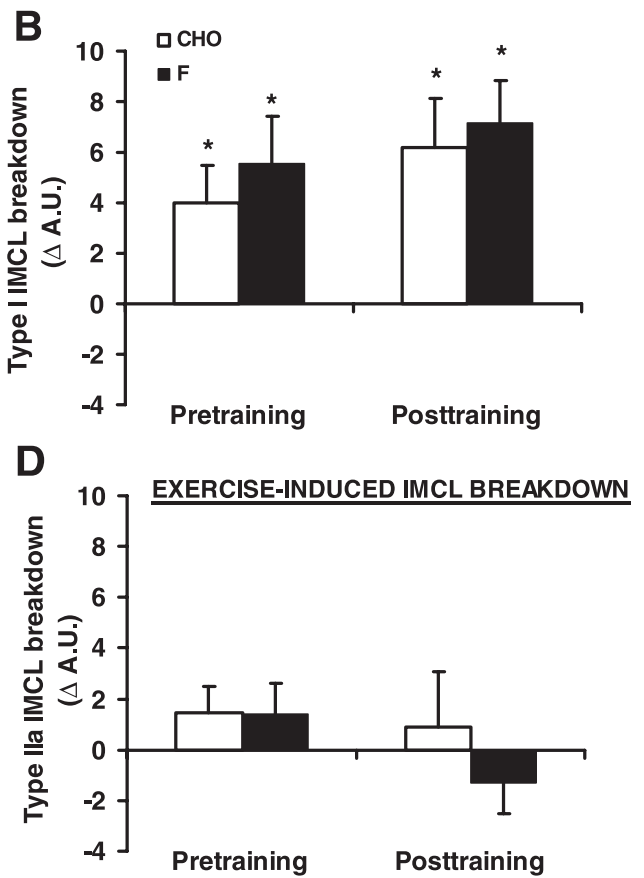

Fig. 5. Effect of training in $\mathrm{F}$ vs. $\mathrm{CHO}$ on intramyocellular triglyceride content (IMCL) content and IMCL breakdown during exercise with carbohydrate intake. Basal IMCL content $(A, C)$ and absolute exercise-induced IMCL breakdown for type I $(A, B)$ and type IIa $(C, D)$ fibers before (Pretraining) and after (Posttraining) a 6-wk training period as determined by fluorescence microscopy on OilRed-O stained muscle cross-sections. Data provided are expressed as means $\pm \mathrm{SE}$ (F: $n=10$; CHO: $n=10) . * P<.05$ significant IMCL breakdown during exercise. same degree in both groups $(P<0.0001)$. Irrespective of training or the experimental conditions, pre-exercise blood glucose concentration was $\sim 4.5 \mathrm{mmol} / \mathrm{l}$. Blood glucose slightly decreased by the end of the 2-h exercise bout, but there were no significant differences between $\mathrm{F}$ and $\mathrm{CHO}$ at any time.

\section{DISCUSSION}

The present study compared the effects of $6 \mathrm{wk}$ of endurance training in the fasted state $(\mathrm{F})$ vs. training in the carbohydrate-

Table 2. Effect of training in the fasted versus carbohydrate-fed state on gas exchange and substrate oxidation calculations during the $2 \mathrm{~h}$ exercise bout with carbohydrate intake

\begin{tabular}{lllr}
\hline \hline & & \multicolumn{2}{c}{ Time } \\
\cline { 3 - 4 } & State & Pretraining & Posttraining \\
\hline Gas exchange & & & \\
$\dot{\mathrm{V}} \mathrm{O}_{2}, \mathrm{ml} / \mathrm{min}$ & $\mathrm{CHO}$ & $2,891 \pm 93$ & $2,733 \pm 128^{*}$ \\
& $\mathrm{~F}$ & $2,904 \pm 110$ & $2,663 \pm 72^{*}$ \\
$\dot{\mathrm{VCO}}_{2}, \mathrm{ml} / \mathrm{min}$ & $\mathrm{CHO}$ & $2,633 \pm 86$ & $2,494 \pm 88^{*}$ \\
& $\mathrm{~F}$ & $2,633 \pm 103$ & $2,406 \pm 46^{*}$ \\
$\mathrm{RER}$ & $\mathrm{CHO}$ & $0.91 \pm 0.01$ & $0.92 \pm 0.01$ \\
& $\mathrm{~F}$ & $0.91 \pm 0.01$ & $0.91 \pm 0.01$ \\
Substrate oxidation & & & \\
Fat, g/min & $\mathrm{CHO}$ & $0.421 \pm 0.07$ & $0.389 \pm 0.07$ \\
& $\mathrm{~F}$ & $0.444 \pm 0.05$ & $0.421 \pm 0.05$ \\
Carbohydrates, g/min & $\mathrm{CHO}$ & $2.74 \pm 0.19$ & $2.62 \pm 0.07$ \\
& $\mathrm{~F}$ & $2.70 \pm 0.16$ & $2.44 \pm 0.08$ \\
\hline
\end{tabular}

Values are expressed as means \pm SE (F: $n=10$; CHO: $n=10)$. Mean oxygen uptake $\left(\mathrm{V}_{2}\right)$, carbon dioxide production $\left(\mathrm{V}_{\mathrm{CO}_{2}}\right)$, and respiratory exchange ratio (RER) as measured after $10 \mathrm{~min}$, halfway through and at the end of the exercise bout over 5-min intervals. Workload during the 2-h exercise bout was fixed at $171 \pm 4 \mathrm{~W}$. Fat and carbohydrate oxidation were calculated using the nonprotein respiratory quotient (see METHODS for further details). $* P<0.05$ for post hoc time effect. No interaction between training and group was detected. fed state $(\mathrm{CHO})$ on resting and exercise-induced muscle gene and protein expression, and the possible implications for energy substrate selection during exercise with carbohydrate intake, which is the recommended dietary condition for endurance performance. We hypothesized that $\mathrm{F}$ is more effective than $\mathrm{CHO}$ to promote adaptations of fat metabolic pathways. In keeping with such hypothesis, $\mathrm{F}$, but not $\mathrm{CHO}$, increased muscle FABPm protein content. However, F caused glycogen sparing rather than stimulating the contribution of total fat oxidation or net IMCL breakdown during submaximal exercise in conjunction with high-rate carbohydrate intake.

When compared with exercise when fed carbohydrates, it is well known that exercise in the fasted state results in lower plasma insulin and higher plasma epinephrine level $(16,20)$ and thus increases the proportion of ATP production from FA oxidation. Along this line, we hypothesized that training while fasting, by virtue of stimulation of fat oxidative pathways, would increase the relative contribution of fat oxidation in total energy production, for a given absolute workload and exercise duration, even in the presence of carbohydrate intake during exercise. However, neither net IMCL breakdown (Fig. 5) nor rate of total fat oxidation (Table 2) was affected by the differential dietary context of the training sessions. In line with our earlier report (16), net IMCL breakdown during exercise in conjunction with carbohydrate intake before and during exercise was small in type I and nearly absent in type II fibers (see Fig. 5). This pattern of IMCL depletion was identical between $\mathrm{F}$ and $\mathrm{CHO}$ and was not affected by the training intervention per se. Furthermore, rate of total fat oxidation, calculated from respiratory gas exchange measurements (see Table 1), was not altered. To prevent progressive glycogen depletion throughout the training period, subjects consistently received a weightmaintaining carbohydrate-rich $(65 \% \mathrm{En})$ diet (1). It is possible that this procedure involving daily high-dose carbohydrate intake inhibited training-induced adaptations to facilitate fat oxidation. Such an assumption is consistent with earlier studies 
Table 3. Effect of training in the fasted versus carbohydrate-fed state on plasma insulin and (nor)epinephrine, and blood glucose concentrations during exercise with carbohydrate intake

\begin{tabular}{|c|c|c|}
\hline & Rest & Exercise \\
\hline \multicolumn{3}{|c|}{ Insulin, $\mu \mathrm{U} / \mathrm{ml}$} \\
\hline \multicolumn{3}{|c|}{ Pretraining } \\
\hline $\mathrm{CHO}$ & $21.0 \pm 4.3$ & $18.9 \pm 5.2$ \\
\hline $\mathrm{F}$ & $37.6 \pm 5.5 \ddagger$ & $17.9 \pm 5.1+\S$ \\
\hline \multicolumn{3}{|c|}{ Postraining } \\
\hline $\mathrm{CHO}$ & $23.7 \pm 4.1$ & $17.4 \pm 4.0$ \\
\hline $\mathrm{F}$ & $31.3 \pm 4.0$ & $17.5 \pm 4.1 \S$ \\
\hline \multicolumn{3}{|c|}{ Epinephrine, $\mu \mathrm{g} / \mathrm{l}$} \\
\hline \multicolumn{3}{|c|}{ Pretraining } \\
\hline $\mathrm{CHO}$ & $0.05 \pm 0.01$ & $0.08 \pm 0.02 \dagger$ \\
\hline $\mathrm{F}$ & $0.07 \pm 0.01$ & $0.12 \pm 0.01 \dagger$ \\
\hline \multicolumn{3}{|c|}{ Posttraining } \\
\hline $\mathrm{CHO}$ & $0.06 \pm 0.01$ & $0.07 \pm 0.01$ \\
\hline $\mathrm{F}$ & $0.07 \pm 0.01$ & $0.11 \pm 0.01 \dagger$ \\
\hline \multicolumn{3}{|c|}{ Norepinephrine, $\mu \mathrm{g} / 1$} \\
\hline \multicolumn{3}{|c|}{ Pretraining } \\
\hline $\mathrm{CHO}$ & $0.46 \pm 0.04$ & $0.73 \pm 0.10 \dagger$ \\
\hline $\mathrm{F}$ & $0.36 \pm 0.03$ & $0.76 \pm 0.11 \dagger$ \\
\hline \multicolumn{3}{|c|}{ Posttraining } \\
\hline $\mathrm{CHO}$ & $0.47 \pm 0.06$ & $0.67 \pm 0.07 \dagger$ \\
\hline $\mathrm{F}$ & $0.41 \pm 0.02$ & $0.64 \pm 0.06+$ \\
\hline \multicolumn{3}{|c|}{ Glucose, $\mathrm{mmol} / \mathrm{l}$} \\
\hline \multicolumn{3}{|c|}{ Pretraining } \\
\hline $\mathrm{CHO}$ & $4.7 \pm 0.2$ & $4.1 \pm 0.4 \dagger$ \\
\hline $\mathrm{F}$ & $4.5 \pm 0.2$ & $4.4 \pm 0.2$ \\
\hline \multicolumn{3}{|c|}{ Posttraining } \\
\hline $\mathrm{CHO}$ & $4.4 \pm 0.2$ & $4.1 \pm 0.2$ \\
\hline $\mathrm{F}$ & $4.3 \pm 0.3$ & $4.0 \pm 0.1 *$ \\
\hline
\end{tabular}

Data provided are means \pm SE (CHO: $n=10 ; \mathrm{F}: n=10)$. Blood glucose and hormones as measured before (Rest) and immediately after (Exercise) exercise in the untrained (pretraining) and trained (posttraining) state. $* P<$ 0.05 vs. pretraining in the same treatment group; $\uparrow P<0.05$ vs. rest; $\ddagger P<0.05$ vs. $\mathrm{CHO}$; §indicates that the exercise-induced decrease is different from $\mathrm{CHO}$.

showing unchanged fat oxidation rates during submaximal exercise following an episode of endurance training in the carbohydrate-repleted state $(1,14,29,57)$, even if exercise is acutely performed in the fasted state (27). Thus our current and previous findings taken together indicate that in conditions of ample carbohydrate availability, muscles preferentially use carbohydrates for energy provision even in the presence of excess potential for fat oxidation, perhaps due to repleted muscle glycogen stores together with high rate exogenous carbohydrate supply before and during exercise.

Fatty acid (FA) transfer from the extracellular space into the cytosol, the initial step in the oxidation of blood-borne FA, is facilitated by the CD36 and FABP membrane proteins (for review, see Refs. 6, 33). Moreover, together with carnitine palmitoyl transferase 1 (CPT1), CD36 is responsible for the uptake of fatty acyl CoA in the mitochondria and thus is a major determinant of intramuscular fat oxidation rate (9). Available studies indicate that long-term exercise training in humans increases FABPm but not CD36 content $(35,56)$. Conversely, CD36 was found to be upregulated after both acute exercise (45) and short-term training (58). Unfortunately, in none of the aforementioned studies, neither the composition of the training diet nor the timing of food intake relative to the training sessions was tightly controlled. In the present study, 6 wk of endurance training in $\mathrm{F}$ increased fat transporter protein content when compared with training with carbohydrate intake, where there was no change at all (Fig. 1). Furthermore, training-induced changes in FABPm and CD36 in F were positively correlated $(r=0.61, P=0.05)$. This could indicate that a high rate of fat oxidation during exercise, as occurs during exercise in a fasted state, is important to training-induced upregulation of muscle fatty acid transporters.

Against the background of unchanged fat oxidation rate, at the end of the 6-wk training period, the amount of net glycogen breakdown in $\mathrm{CHO}\left(\sim 150 \mathrm{mmol} \cdot \mathrm{kg} \mathrm{dry} \mathrm{wt^{-1 }} \cdot \mathrm{h}^{-1}\right)$ was more than double the amount in $\mathrm{F}\left(\sim 70 \mathrm{mmol} \cdot \mathrm{kg}\right.$ dry $\mathrm{wt}^{-1} \cdot \mathrm{h}^{-1}$; Fig. 4). It is well known that high initial muscle glycogen concentration can enhance rate of net glycogen breakdown during exercise $(2,26,30)$. Therefore, one might argue that the higher rate of glycogenolysis occurring in $\mathrm{CHO}$ was simply due to higher initial muscle glycogen content $(25 \%, P=0.01)$ compared with F. However, regression analysis shows that the differential dietary contexts of training $(\mathrm{F}$ vs . $\mathrm{CHO}$ ) altered the relationship between initial glycogen level and the degree of net glycogen breakdown during exercise. As shown in Fig. 4, in $\mathrm{CHO}$ net glycogen degradation for a given initial glycogen level was enhanced by the training period and significantly higher than in $\mathrm{F}(P=0.04)$. Thus exercise training in the fasted state, during which glycogen breakdown as well as FA oxidation both are acutely enhanced $(15,16)$, induces glycogen sparing when exercise is performed in combination with carbohydrate intake. This decrease was probably compensated for by an increase in blood glucose oxidation, resulting in lower blood glucose concentration at the end of the 2-h exercise bout (see Table 3). The increase in blood glucose oxidation during exercise requires upregulation of muscle glucose uptake (43). It is known that, despite higher total muscle GLUT4 content, endurance training is characterized by a decrease in exercise-induced glucose uptake due to impaired GLUT4 translocation when exercise is carried out at the same absolute intensity before and after training $(44,61)$. The mechanisms underlying this endurance training-induced "desensitization" of GLUT4 translocation is currently unknown. However, our current observations seem to indicate that regular exercise in the fasted state might stimulate muscle glucose uptake for a given absolute exercise intensity when carbohydrates are taken, which in turn inhibits net glycogenolysis. Alternatively, decreased glycogen breakdown rate during exercise may also have stimulated blood glucose utilization. Future studies must investigate the validity of either alternative mechanism.

Cross-sectional studies in endurance athletes vs. lean sedentary subjects $(19,23,46,59)$ have fostered the opinion that endurance training elevates basal IMCL content. The reportedly higher IMCL content in endurance athletes at least partly reflects higher proportion of type I fibers (59). Data from training studies in young healthy volunteers are equivocal, with some studies reporting increased $(48,51)$, unchanged (7), or even decreased (4) IMCL content. Because an increased proportion of dietary fat can rapidly change IMCL content $(3,34)$, subjects in the current study were put on a strictly controlled carbohydrate-rich diet. With this dietary regimen, IMCL content was unchanged by the training intervention in either fiber type, independent of the experimental group. We previously showed increased IMCL as an early response to endurance training (51). In this study, at the end of a 2-wk training period 
subjects were put on a 30\% fat diet for 3 days while exercise training was ceased. This condition facilitates a more pronounced degree of IMCL synthesis (18) when compared with the present study where fat intake was lower $(\sim 20 \%)$ and biopsies were taken only $\sim 48 \mathrm{~h}$ after the last training session. Thus, although literature remains equivocal, probably due to differential dietary conditions between studies that usually remain unreported, the current findings indicate that short-term endurance training in conjunction with a carbohydrate-rich diet, which is typical for athletes, does not increase basal IMCL content in non-endurance trained male subjects. Consistent with such contention are findings from a cross-sectional study wherein IMCL content was similar between untrained volunteers and endurance trained subjects after an 8-day standardized carbohydrate-rich diet, despite higher proportion of type I fibers in the trained (55).

A single bout of exercise in the fasted state upregulates gene expression of several metabolic genes, whereas these perturbations are blunted by increased insulin levels due to carbohydrate intake $(11,16)$. Therefore, another aim of the present study was to compare the effects of $\mathrm{F}$ vs. $\mathrm{CHO}$ on the acute gene responses to exercise performed in combination with carbohydrate intake. To date only a small number of studies have looked at the effect of training on the acute gene responses to an endurance exercise bout $(37,38,47,58,60)$. The changes of muscle mRNA content reported were highly specific for the genes considered and the exercise protocol used. In one study, exercise-induced upregulation of lipid metabolic genes was increased after training, whereas genes involved in insulin signaling were suppressed $(58,60)$. However, in the latter study, the short training period (9 days) increased fat oxidation rate by $\sim 25 \%$ during a 1 -h cycling bout in the fasted state. In contrast, in the current study such training-induced substrate shift was negated by the high-rate carbohydrate intake during exercise, which conceivably also blunted exercise effects on mRNA levels in both F and CHO (see Figs. 2 and 3). This probably indicates that acute dietary factors may be more dominant than short-term training effects to modulate exercise-induced changes in gene transcription.

In most physically active individuals, exercise training serves to increase health and fitness. However, in athletes, endurance performance is the absolute training focus. In either case it is important to seek for optimal training strategies to achieve the specific training goals. For instance, there are recent data to indicate that training twice daily every second day is more effective to induce muscular adaptations and enhance endurance performance than training once daily (24). The greater effectiveness of the former strategy was explained by low muscle glycogen content in part of the training sessions. Still, in most individuals, high-intensity training twice daily is not a practicable time schedule to facilitate training adaptations. Training in the fasted state, i.e., decreasing exogenous carbohydrate supply, could provide a valid adjuvant stimulus to enhance training adaptations. Unfortunately, adaptations specific to training while fasting, for instance increased fat transporter protein content and suppressed exercise-induced net muscle glycogen breakdown, hardly exceeded overall training adaptations in the present study and did not affect whole body fat oxidation rates. Future studies must therefore reveal whether exercise training in the fasted state for longer periods than the $6 \mathrm{wk}$ used in the present study will yield more beneficial effects in endurance trained individuals.

In conclusion, the current study for the first time shows that adaptations to short-term endurance training in the fasted state are largely similar to training in the carbohydrate-fed state. Still, training-induced upregulation of fat transporter protein content was completely inhibited in CHO. Furthermore, although training in the fasted state did not result in increased rate of fat oxidation during exercise with carbohydrate intake, glycogen breakdown was lower when compared with $\mathrm{CHO}$. Further studies must investigate whether this glycogen sparing action is beneficial for endurance performance.

\section{ACKNOWLEDGMENTS}

Monique Ramaekers and Gert Schaart are greatly acknowledged for all efforts they have put in this study. Thanks to all subjects for participating in this study.

\section{GRANTS}

The study was supported by grants from the Onderzoeksraad K.U.Leuven (Grant No. OT04/45), the Fonds voor Wetenschappelijk Onderzoek Vlaanderen (Grant No. G.0233.05), from the Copenhagen Muscle Research Centre, the Media and Grants Secretariat of the Danish Ministry of Culture, the Danish Diabetes Association, the Novo Nordisk Foundation, the Danish Medical Research Council, and the European Commission (Integrated Project LSHMCT-2004-005272), the Canadian Institutes of Health Research the Natural Sciences and Engineering Research Council of Canada, and the Canada Research Chair program. K. De Bock obtained a postdoctoral research fellowship from the Onderzoeksraad K.U.Leuven. A. Bonen is the Canada Research Chair in Metabolism and Health.

\section{REFERENCES}

1. Achten J, Halson SL, Moseley L, Rayson MP, Casey A, Jeukendrup AE. Higher dietary carbohydrate content during intensified running training results in better maintenance of performance and mood state. J Appl Physiol 96: 1331-1340, 2004.

2. Arkinstall MJ, Bruce CR, Clark SA, Rickards CA, Burke LM, Hawley JA. Regulation of fuel metabolism by preexercise muscle glycogen content and exercise intensity. J Appl Physiol 97: 2275-2283, 2004.

3. Bachmann OP, Dahl DB, Brechtel K, Machann J, Haap M, Maier T, Loviscach M, Stumvoll M, Claussen CD, Schick F, Haring HU, Jacob S. Effects of intravenous and dietary lipid challenge on intramyocellular lipid content and the relation with insulin sensitivity in humans. Diabetes 50: 2579-2584, 2001 .

4. Bergman BC, Butterfield GE, Wolfel EE, Casazza GA, Lopaschuk GD, Brooks GA. Evaluation of exercise and training on muscle lipid metabolism. Am J Physiol Endocrinol Metab 276: E106-E117, 1999.

5. Bonen A, Parolin ML, Steinberg GR, Calles-Escandon J, Tandon NN, Glatz JF, Luiken JJ, Heigenhauser GJ, Dyck DJ. Triacylglycerol accumulation in human obesity and type 2 diabetes is associated with increased rates of skeletal muscle fatty acid transport and increased sarcolemmal FAT/CD36. FASEB J 18: 1144-1146, 2004.

6. Bonen A, Chabowski A, Luiken JJFP, Glatz JFC. Mechanisms and regulation of protein-mediated cellular fatty acid uptake: molecular, biochemical, and physiological evidence. Physiology 22: 15-28, 2007.

7. Bruce CR, Kriketos AD, Cooney GJ, Hawley JA. Disassociation of muscle triglyceride content and insulin sensitivity after exercise training in patients with Type 2 diabetes. Diabetologia 47: 23-30, 2004.

8. Burke LM, Kiens B. "Fat adaptation" for athletic performance: the nail in the coffin? J Appl Physiol 100: 7-8, 2006.

9. Campbell SE, Tandon NN, Woldegiorgis G, Luiken JJFP, Glatz JFC, Bonen A. A novel function for fatty acid translocase (FAT)/CD36: involvement in long chain fatty acid transfer into the mitochondria. $J$ Biol Chem 279: 36235-36241, 2004.

10. Chryssanthopoulos C, Williams C, Nowitz A, Kotsiopoulou C, Vleck V. The effect of a high carbohydrate meal on endurance running capacity. Int J Sport Nutr Exerc Metab 12: 157-171, 2002.

11. Civitarese AE, Hesselink MK, Russell AP, Ravussin E, Schrauwen P. Glucose ingestion during exercise blunts exercise-induced gene expression 
of skeletal muscle fat oxidative genes. Am J Physiol Endocrinol Metab 289: E1023-E1029, 2005.

12. Coggan AR, Coyle EF. Carbohydrate ingestion during prolonged exercise: effects on metabolism and performance. Exerc Sport Sci Rev 19: $1-40,1991$

13. Coyle EF, Coggan AR, Hopper MK, Walters TJ. Determinants of endurance in well-trained cyclists. J Appl Physiol 64: 2622-2630, 1988.

14. Coyle EF, Jeukendrup AE, Oseto MC, Hodgkinson BJ, Zderic TW. Low-fat diet alters intramuscular substrates and reduces lipolysis and fat oxidation during exercise. Am J Physiol Endocrinol Metab 280: E391E398, 2001.

15. De Bock K, Derave W, Ramaekers M, Richter EA, Hespel P. Fiber type-specific muscle glycogen sparing due to carbohydrate intake before and during exercise. J Appl Physiol 102: 183-188, 2007.

16. De Bock K, Richter EA, Russell AP, Eijnde BO, Derave W, Ramaekers M, Koninckx E, Leger B, Verhaeghe J, Hespel P. Exercise in the fasted state facilitates fibre type-specific intramyocellular lipid breakdown and stimulates glycogen resynthesis in humans. J Physiol 564: 649-660, 2005.

17. De Glisezinski I, Harant I, Crampes F, Trudeau F, Felez A, CottetEmard JM, Garrigues M, Riviere D. Effect of carbohydrate ingestion on adipose tissue lipolysis during long-lasting exercise in trained men. $J$ Appl Physiol 84: 1627-1632, 1998.

18. Decombaz J, Fleith M, Hoppeler H, Kreis R, Boesch C. Effect of diet on the replenishment of intramyocellular lipids after exercise. Eur J Nutr 39: $244-247,2000$.

19. Decombaz J, Schmitt B, Ith M, Decarli B, Diem P, Kreis R, Hoppeler H, Boesch C. Postexercise fat intake repletes intramyocellular lipids but no faster in trained than in sedentary subjects. Am J Physiol Regul Integr Comp Physiol 281: R760-R769, 2001.

20. Febbraio MA, Chiu A, Angus DJ, Arkinstall MJ, Hawley JA. Effects of carbohydrate ingestion before and during exercise on glucose kinetics and performance. J Appl Physiol 89: 2220-2226, 2000.

21. Febbraio MA, Steensberg A, Walsh R, Koukoulas I, van Hall G, Saltin B, Pedersen BK. Reduced glycogen availability is associated with an elevation in HSP72 in contracting human skeletal muscle. $J$ Physiol 538: 911-917, 2002.

22. Frosig C, Jorgensen SB, Hardie DG, Richter EA, Wojtaszewski JFP. 5 '-AMP-activated protein kinase activity and protein expression are regulated by endurance training in human skeletal muscle. Am J Physiol Endocrinol Metab 286: E411-E417, 2004.

23. Goodpaster BH, He J, Watkins S, Kelley DE. Skeletal muscle lipid content and insulin resistance: evidence for a paradox in endurance-trained athletes. J Clin Endocrinol Metab 86: 5755-5761, 2001.

24. Hansen AK, Fischer CP, Plomgaard P, Andersen JL, Saltin B, Pedersen BK. Skeletal muscle adaptation: training twice every second day vs. training once daily. J Appl Physiol 98: 93-99, 2005.

25. Hargreaves M, Briggs CA. Effect of carbohydrate ingestion on exercise metabolism. J Appl Physiol 65: 1553-1555, 1988.

26. Hargreaves M, McConell G, Proietto J. Influence of muscle glycogen on glycogenolysis and glucose uptake during exercise in humans. $J$ Appl Physiol 78: 288-292, 1995.

27. Helge JW, Richter EA, Kiens B. Interaction of training and diet on metabolism and endurance during exercise in man. J Physiol 492: 293306, 1996.

28. Helge JW, Watt PW, Richter EA, Rennie MJ, Kiens B. Fat utilization during exercise: adaptation to a fat-rich diet increases utilization of plasma fatty acids and very low density lipoprotein-triacylglycerol in humans. J Physiol 537: 1009-1020, 2001.

29. Helge JW, Wulff B, Kiens B. Impact of a fat-rich diet on endurance in man: role of the dietary period. Med Sci Sports Exerc 30: 456-461, 1998.

30. Hespel P, Richter EA. Mechanism linking glycogen concentration and glycogenolytic rate in perfused contracting rat skeletal muscle. Biochem $J$ 284: 777-780, 1992.

31. Hoeks J, Hesselink MK, Sluiter W, Schaart G, Willems J, Morrisson A, Clapham JC, Saris WH, Schrauwen P. The effect of high-fat feeding on intramuscular lipid and lipid peroxidation levels in UCP3-ablated mice. FEBS Lett 580: 1371-1375, 2006.

32. Jeukendrup AE. Carbohydrate intake during exercise and performance. Nutrition 20: 669-677, 2004.

33. Kiens B. Skeletal muscle lipid metabolism in exercise and insulin resistance. Physiol Rev 86: 205-243, 2006.

34. Kiens B, Essen-Gustavsson B, Gad P, Lithell H. Lipoprotein lipase activity and intramuscular triglyceride stores after long-term high-fat and high-carbohydrate diets in physically trained men. Clin Physiol 7: 1-9, 1987.

35. Kiens B, Kristiansen S, Jensen P, Richter EA, Turcotte LP. Membrane associated fatty acid binding protein (FABPpm) in human skeletal muscle is increased by endurance training. Biochem Biophys Res Comm 231: 463-465, 1997.

36. Lowry OH, Passoneau JV. A Flexible System of Enzymatic Analysis. New York: Academic, 1972.

37. Lundby C, Gassmann M, Pilegaard H. Regular endurance training reduces the exercise induced HIF-1alpha and HIF-2alpha mRNA expression in human skeletal muscle in normoxic conditions. Eur J Appl Physiol 96: 363-369, 2006.

38. Nordsborg N, Bangsbo J, Pilegaard H. Effect of high-intensity training on exercise-induced gene expression specific to ion homeostasis and metabolism. J Appl Physiol 95: 1201-1206, 2003.

39. Op't EB, Urso B, Richter EA, Greenhaff PL, Hespel P. Effect of oral creatine supplementation on human muscle GLUT4 protein content after immobilization. Diabetes 50: 18-23, 2001.

40. Peronnet F, Massicotte $\mathbf{D}$. Table of nonprotein respiratory quotient: an update. Can J Sport Sci 16: 23-29, 1991.

41. Pilegaard H, Neufer PD. Transcriptional regulation of pyruvate dehydrogenase kinase 4 in skeletal muscle during and after exercise. Proc Nutr Soc 63: 221-226, 2004.

42. Pilegaard H, Keller C, Steensberg A, Helge JW, Pedersen BK, Saltin B, Neufer PD. Influence of pre-exercise muscle glycogen content on exercise-induced transcriptional regulation of metabolic genes. $J$ Physiol 541: 261-271, 2002.

43. Richter EA, Derave W, Wojtaszewski JF. Glucose, exercise and insulin: emerging concepts. J Physiol 535: 313-322, 2001.

44. Richter EA, Jensen P, Kiens B, Kristiansen S. Sarcolemmal glucose transport and GLUT-4 translocation during exercise are diminished by endurance training. Am J Physiol Endocrinol Metab 274: E89-E95, 1998.

45. Roepstorff C, Vistisen B, Roepstorff K, Kiens B. Regulation of plasma long-chain fatty acid oxidation in relation to uptake in human skeletal muscle during exercise. Am J Physiol Endocrinol Metab 287: E696-E705, 2004.

46. Russell AP, Gastaldi G, Bobbioni-Harsch E, Arboit P, Gobelet C, Deriaz O, Golay A, Witztum JL, Giacobino JP. Lipid peroxidation in skeletal muscle of obese compared with endurance-trained humans: a case of good vs. bad lipids? FEBS Lett 551: 104-106, 2003.

47. Schmutz S, Dapp C, Wittwer M, Vogt M, Hoppeler H, Fluck M. Endurance training modulates the muscular transcriptome response to acute exercise. Pflugers Arch 451: 678-687, 2006.

48. Schrauwen P, Aggel-Leijssen DP, Hul G, Wagenmakers AJ, Vidal H, Saris WH, van Baak MA. The effect of a 3-month low-intensity endurance training program on fat oxidation and acetyl-CoA carboxylase-2 expression. Diabetes 51: 2220-2226, 2002.

49. Schrauwen P, Hesselink MK, Blaak EE, Borghouts LB, Schaart G, Saris WH, Keizer HA. Uncoupling protein 3 content is decreased in skeletal muscle of patients with type 2 diabetes. Diabetes 50: 2870-2873, 2001.

50. Schrauwen P, Hesselink MK, Vaartjes I, Kornips E, Saris WH, Giacobino JP, Russell A. Effect of acute exercise on uncoupling protein 3 is a fat metabolism-mediated effect. Am J Physiol Endocrinol Metab 282: E11-E17, 2002.

51. Schrauwen-Hinderling VB, Schrauwen P, Hesselink MK, van Engelshoven JM, Nicolay K, Saris WH, Kessels AG, Kooi ME. The increase in intramyocellular lipid content is a very early response to training. J Clin Endocrinol Metab 88: 1610-1616, 2003.

52. Sherman WM, Costill DL, Fink WJ, Miller JM. Effect of exercise-diet manipulation on muscle glycogen and its subsequent utilization during performance. Int J Sports Med 2: 114-118, 1981.

53. Short KR, Vittone JL, Bigelow ML, Proctor DN, Rizza RA, CoenenSchimke JM, Nair KS. Impact of aerobic exercise training on age-related changes in insulin sensitivity and muscle oxidative capacity. Diabetes 52 : 1888-1896, 2003.

54. Simonsen JC, Sherman WM, Lamb DR, Dernbach AR, Doyle JA, Strauss R. Dietary carbohydrate, muscle glycogen, and power output during rowing traning. J Appl Physiol 70: 1500-1505, 1991.

55. Steffensen CH, Roepstorff C, Madsen M, Kiens B. Myocellular triacylglycerol breakdown in females but not in males during exercise. Am J Physiol Endocrinol Metab 282: E634-E642, 2002.

56. Talanian JL, Galloway SDR, Heigenhauser GJF, Bonen A, Spriet LL. Two weeks of high-intensity aerobic interval training increases the capac- 
ity for fat oxidation during exercise in women. J Appl Physiol 102: 1439-1447, 2007.

57. Tarnopolsky MA, Rennie C, Robertshaw HA, Fedak-Tarnopolsky SN, Devries MC, Hamadeh MJ. Influence of endurance exercise training and sex on intramyocellular lipid and mitochondrial ultrastructure, substrate use, and mitochondrial enzyme activity. Am J Physiol Regul Integr Comp Physiol 292: R1271-R1278, 2007.

58. Tunstall RJ, Mehan KA, Wadley GD, Collier GR, Bonen A, Hargreaves M, Cameron-Smith D. Exercise training increases lipid metabolism gene expression in human skeletal muscle. Am J Physiol Endocrinol Metab 283: E66-E72, 2002.
59. Van Loon LJ, Koopman R, Manders R, Van Der WW, Van Kranenburg GP, Keizer HA. Intramyocellular lipid content in type 2 diabetes patients compared with overweight sedentary men and highly trained endurance athletes. Am J Physiol Endocrinol Metab 287: E558-E565, 2004.

60. Wadley GD, Tunstall RJ, Sanigorski A, Collier GR, Hargreaves M, Cameron-Smith D. Differential effects of exercise on insulin-signaling gene expression in human skeletal muscle. J Appl Physiol 90: 436-440, 2001.

61. Wojtaszewski JF, Richter EA. Glucose utilization during exercise: influence of endurance training. Acta Physiol Scand 162: 351-358, 1998.

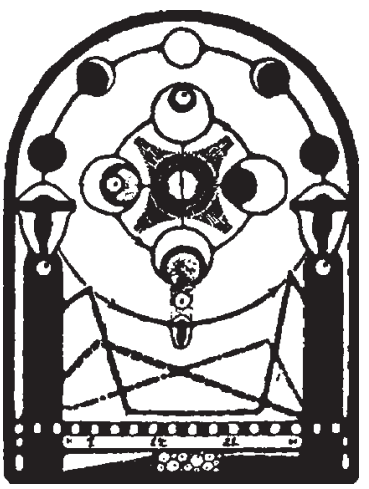

